\title{
[5.
}

\section{Cytotoxic Activity Of Non Polar Fraction From Annona Muricata L. Leaves On Hela And Raji Cell Line}

\author{
Anif Nur Artanti ${ }^{1}$, Okid Parama Astirin ${ }^{2}$, Adi Prayitno ${ }^{3}$ \\ 1) Department of Pharmacy, Faculty of Mathematics and Natural Science, University of Sebelas \\ Maret, Surakarta, Indonesia \\ 2) Department of Biology, Faculty of Mathematics and Natural Science, University of Sebelas Maret, \\ Surakarta, Indonesia \\ 3) Department of Dental and Oral Disease, Faculty of Medicine, University of Sebelas Maret, \\ Surakarta, Indonesia
}

*Corresponding author, email : antantinuranif@gmail.com

\begin{abstract}
The main focus of the research is cancer by a viral infection such as nasopharinx and cervical cancer that have high incidence in Indonesia. Cervical cancer is due to the viral infection known as the Human Papilloma Virus (HPV) and nasopharing cancer is a cancer that is caused by EBV infection (Eppstein Barr virus). The main priority of nasopharinx and servix cancer treatment is the use of chemotherapeutic agents, but it might also lead to diverse side-effects. The focus of this study was to develop the potency of non polar fraction from Annona muricata L. leaves by observing the cytotoxic effect on Hela and Raji cancer cell line.
\end{abstract}

Methods Annona muricata L. leaves was extracted with ethanol, evaporated and partitioned with chloroform, $n$-hexane and ethyl acetate by vaccum colomb chromatography (VLC). The fractions was evaporated by using rotary evaporator and identified with KLT. Each sample from KLT process which have one spot is joined and evaporated again. Cytotoxic activity of non polar fraction from Annona muricata L. leaves was evaluated using MTT assay to obtain the value of $\mathrm{IC}_{50}$ on Hela and Raji cell lines.

Result Chloroform, $n$-hexane and ethyl acetate fractions from Annona muricata L. leaves performed cytotoxic effect on Raji cells with $\mathrm{IC}_{50}$ of $90,6 \mu \mathrm{g} / \mathrm{ml}, 407,2 \mu \mathrm{g} / \mathrm{ml}$ and 260,2 $\mu \mathrm{g} / \mathrm{ml}$ resepectively. Cytotoxic effect of chloroform and $n$-hexane fraction from Annona muricata $\mathrm{L}$ on Hela cell with $\mathrm{IC}_{50}$ of $127,3 \mu \mathrm{g} / \mathrm{ml}, 169,2 \mu \mathrm{g} / \mathrm{ml}$.

Conclusion The result demonstrate that the chloroform fraction from Annona muricata L. leaves exert potent cytotoxic effect on Raji and Hela cells. Further chemical and pharmalogical investigation were carried out and the major isolates were quickly obtain at present time to evaluated the anticancer of Annona Muricata L.

Keyword : cytotoxicity, chloroform, n-heksana, ethyl acetate, Annona muricata L., Raji cells, Hela cells. 


\section{Introduction}

Cancer is the most deadly in the world with molecular cause that has each type. The estimate of cancer caused by infectious agent more than 20\% (IARC,2009). The main focus of the research is cancer by a viral infection such as nasopharinx and cervical cancer that have high incidence in Indonesia. Cervical cancer is due to the viral infection known as the Human Papilloma Virus (HPV) and nasopharing cancer is a cancer that is caused by EBV infection (Eppstein Barr virus). The incidence of cancer caused by virus is increasing every year, with estimation of new cases of cervical cancer caused by HPV infection is increase $2 \%$ per annum to 770,000 (Forman et al., 2012) and the estimated number of person infected with EBV is more than 5,5 billion (Chen, et al., 2014). The viral factor associated with oncogenic include the persisten infection, elevated viralload, virus genotype and variants (IARC, 2009). There are several ways to treat cancer caused by virus such as surgery, radiation therapy, chemotherapy, and combination of these. To date, the useof chemotherapeutic agent is the mostly used treatment (Leaver and Labonte, 2010) but it cause many side effects, such as severe nausea and vomiting,acute and chronic nephrotoxicity, anemia (Miller et al., 2010; Rabik and Dolan,2007), acute cochlear toxicity (ototoxicity) (Mukherjea and Rybak, 2011) and also developed resistance (Sirichanchuen et al., 2012). Many studies was conducted on natural compound as an anticancer agent (Newman, D.J, and Cragg, G.M, 2007) that has shown potentially of anti-cancer that have toxicity selectively without damaging in normal cells (Lee, 2010). One of the natural compound which has potential effect as anticancer agent is Annona muricata Linn.C.C Liaw et. al., 2002 reported that four compound of Annona muricata Linn. have a potential anticancer namely are monotetrahydofuran acetogenins, muricin $\mathrm{H}$, muricin I and cis-annomontacin. Therefore, the aim of this research was to develop the potency of non polar fraction from Annona muricata Linn as chemotherapeutic agentof cancer nasopharink and cervix. The focus of this study was to observe the cytotoxic effectof it.

\section{Metodology}

\subsection{Sample Preparation}

Annona muricata L. leaves was obtained from Karanganyar, Central Java, Indonesia. It leaves was extracted with ethanol, evaporated and partitioned with chloroform, $n$-hexane and ethyl acetate by vaccum colomb chromatography (VLC).

The fractions was evaporated by using rotary evaporator and identified with KLT. Each sample from KLT process which have one spot is joined and evaporated again.

\subsection{Cell culture}

Hela and Raji cells were obtained from LPPT, Gadjah Mada University and were grown in RPMI (Gibco), supplemented with 10\% Fetal Bovine Serum (FBS Qualified, Gibco, Invitrogen 
USA), $1.5 \%$ (w/w) penisilin-streptomisin (Gibco, Invitrogen USA), and $0.5 \%$ fungizone (Gibco, Invitrogen USA). Cells were incubated at $37^{\circ} \mathrm{C}$ and $5 \% \mathrm{CO}_{2}$.

\subsection{MTT assay}

Cytotoxic activity of non polar fraction from Annona muricata L. leaves was evaluated using MTT assay to obtain the value of $\mathrm{IC}_{50} .12 \times 10^{3} \mathrm{Hela}$ and Raji cells/well were grown in 96-well plate before being exposured to drug treatment. For cell viability assay, cells were treated for 24 hours with increasing concentration of non polar fraction from Annona muricata alone. As negative control, only growth medium was added. At $100 \mu \mathrm{g} / \mathrm{ml}$ of MTT solution $(0.5 \mathrm{mg} / \mathrm{ml}$ in PBS) was added to each well continued with incubation for 3 hours at $37^{\circ} \mathrm{C}$. The reaction was stopped by dilution with $10 \%$ (w/v) Sodium Dodecyl Sulphate in $0.01 \mathrm{~N} \mathrm{HCl}$, and cells were incubated overnight. The absorbance was determined by using ELISA reader at $\lambda 595 \mathrm{~nm}$.

\subsection{Statistical analysis}

Cell viability were analyzed statistically by using Microsoft Excell to obtain $\mathrm{IC}_{50}$ value and statistical significance was estimated by using ANOVA test. Statistical significance was placed at $\mathrm{P}<0.05$

\section{Result}

Non polar fraction from Annona muricata L. leaves shows potent cytotoxicity on Hela and Raji cells. Furthermore, $\mathrm{IC}_{50}$ value acquired as the parameter of concentration that needed to yield $50 \%$ cells' growth inhibition of non polar fraction from Annona muricata L. leaves on Hela and Raji cells. The effect of non polar fraction to cell viability of 24-hours treatment. Treated cells showed cytotoxic effect with change of cell morphology and decreased cell viability. Viable cells had epithelial shape, but after being treated with certain concentration of samples they gave spherical-shape and shrunk cell wall. Non polar fracion caused inhibition of cell growth in a concentration-dependent manner (Fig.1-6). Chloroform, $n$-hexane and ethyl acetate fractions from Annona muricata L. leaves performed cytotoxic effect on Raji cells with IC $_{50}$ of 90,6 $\mu \mathrm{g} / \mathrm{ml}, 407,2 \mu \mathrm{g} / \mathrm{ml}$ and 260,2 $\mu \mathrm{g} / \mathrm{ml}$ resepectively. Cytotoxic effect of chloroform and $n$-hexane fraction from Annona muricata $\mathrm{L}$ on Hela cell with $\mathrm{IC}_{50}$ of $127,3 \mu \mathrm{g} / \mathrm{ml}, 169,2 \mu \mathrm{g} / \mathrm{ml}$

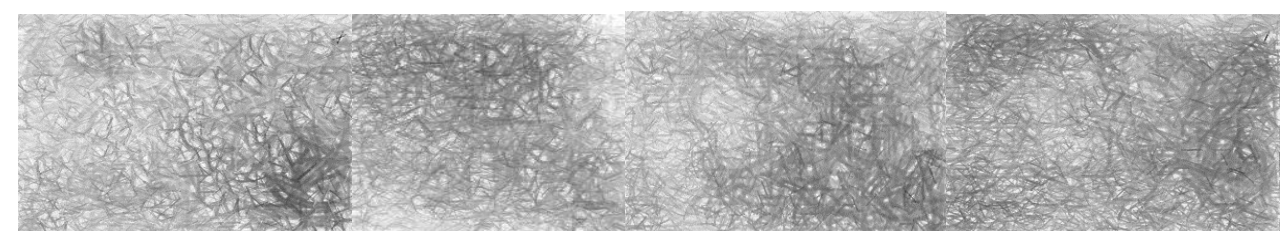

(a) (b) (c) (d)

Fig. 1. Cytotoxic effect on Raji cells. Morpholgy of Raji cells, (a) cell control ; 24 hours treatment with Annona muricata Linn. Leaves (b) chloroform fraction $61 \mu \mathrm{g} / \mathrm{ml}$; (c) chloroform fraction $125 \mu \mathrm{g} / \mathrm{ml}$ (d) chloroform fraction $250 \mu \mathrm{g} / \mathrm{ml}$ 


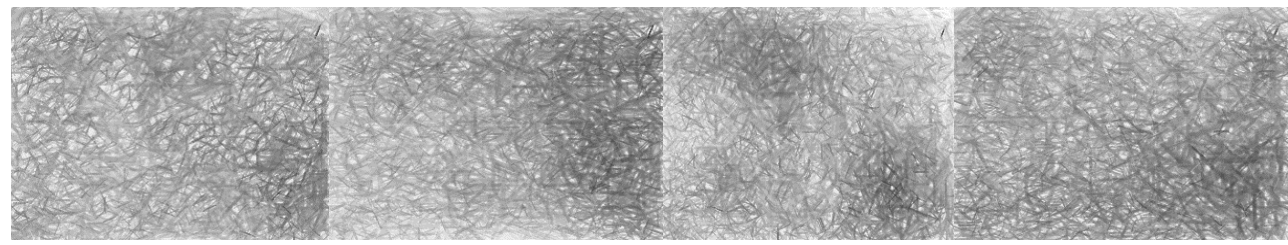

(a)

(b)

(c)

(d)

Fig. 2. Cytotoxic effect on Raji cells. Morpholgy of Raji cells, (a) cell control ; 24 hours treatment with Annona muricata Linn. Leaves (b) ethyl acetate fraction $61 \mu \mathrm{g} / \mathrm{ml}$; (c) ethyl acetate fraction $125 \mu \mathrm{g} / \mathrm{ml}$ (d) ethyl acetate fraction $250 \mu \mathrm{g} / \mathrm{ml}$

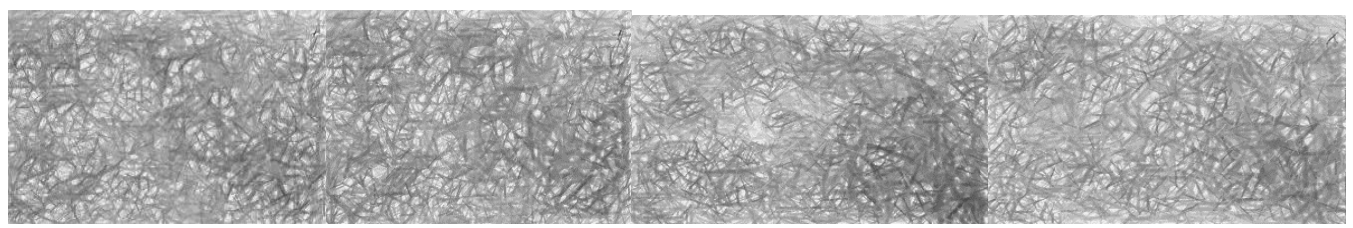

(a)

(b)

(c)

(d)

Fig. 3. Cytotoxic effect on Raji cells. Morpholgy of Raji cells, (a) cell control ; 24 hours treatment with Annona muricata Linn. Leaves (b) n-hexane fraction $61 \mu \mathrm{g} / \mathrm{ml}$; (c) n-hexane fraction $125 \mu \mathrm{g} / \mathrm{ml}$ (d) n-hexane fraction $250 \mu \mathrm{g} / \mathrm{ml}$

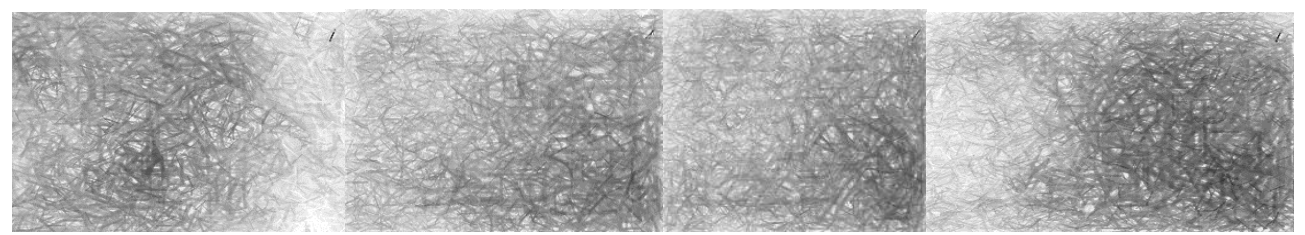

(a)

(b)

(c)

(d)

Fig. 4. Cytotoxic effect on Hela cells. Morpholgy of Hela cells, (a) cell control ; 24 hours treatment with Annona muricata Linn. Leaves (b) chloroform fraction $61 \mu \mathrm{g} / \mathrm{ml}$; (c) chloroform fraction $125 \mu \mathrm{g} / \mathrm{ml}$ (d) chloroform fraction $250 \mu \mathrm{g} / \mathrm{ml}$

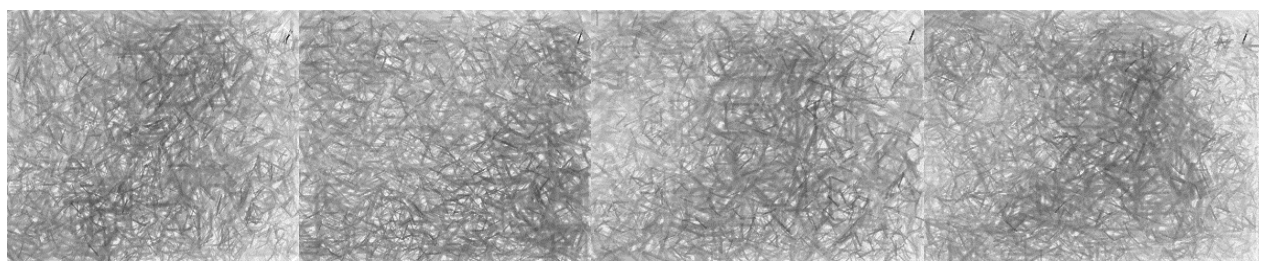

(a)

(b)

(c)

(d)

Fig. 5. Cytotoxic effect on Hela cells. Morpholgy of Hela cells, (a) cell control ; 24 hours treatment with Annona muricata Linn. Leaves (b) ethyl acetate fraction $61 \mu \mathrm{g} / \mathrm{ml}$; (c) ethyl acetate fraction $125 \mu \mathrm{g} / \mathrm{ml}$ (d) ethyl acetate fraction $250 \mu \mathrm{g} / \mathrm{ml}$ 


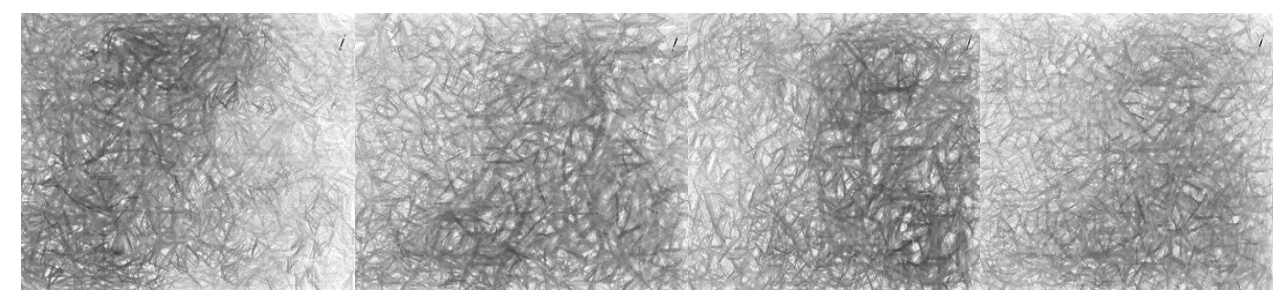

(a)

(b)

(c)

(d)

Fig. 6. Cytotoxic effect on Hela cells. Morpholgy of Hela cells, (a) cell control ; 24 hours treatment with Annona muricata Linn. Leaves (b) n-hexane fraction $61 \mu \mathrm{g} / \mathrm{ml}$; (c) n-hexane fraction $125 \mu \mathrm{g} / \mathrm{ml}$ (d) n-hexane fraction $250 \mu \mathrm{g} / \mathrm{ml}$

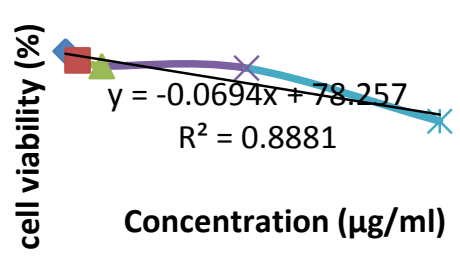

(a)

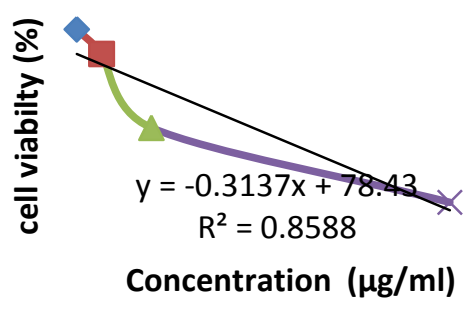

(b)

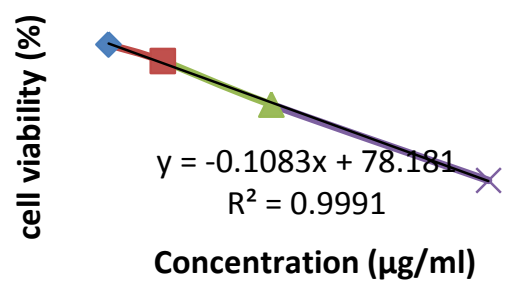

(c)

Fig. 7. Decreasing of cell viability after treated with (a) chloroforom fraction (b) ethyl acetate fraction (c) n-hexane fraction from Annona muricata Linn leaves on Raji cell.

Cell viability after treatment with chloroform fraction from Annona muricata Linn. was significantly decreased by $\mathrm{IC}_{50}$ value is $90,6 \mu \mathrm{g} / \mathrm{ml}$ on Raji cells (Fig.7). According to Prayong et al. (2008) this active compound exhibited potent cytotoxicity $\left(\mathrm{IC}_{50} \leq 100 \mu \mathrm{g} / \mathrm{ml}\right)$. These results above suggested that chloroform fraction from Annona muricata Linn leaves indicate as the most potential concentration which has potentialcytotoxiceffect. 


\section{Discussion}

The study for anticancer agent from natural source has been succesfull worldwide. Active constituens have been purified and nowadays used to treat in human tumours. The etnopharmacological knowledge is helpful to lead the study for plant which has potential cytotoxic activity. Annona muricata L. reported to be utilises as remedies againts cancer, however is not especially for cancer caused virus. Our result demonstrated that non polar fractions for Annona muricata L. have growth inhibitory and cytotoxic effect on nasopharing and cervix cancer cell line. Chloroform fraction from Annona muricata Linn leaves performed more potent cytotoxic effect on Raji cells compared to n-hexane fraction ( $\mathrm{IC}_{50}$ value of $407,2 \mu \mathrm{g} / \mathrm{ml}$ ) and etyl acetate fraction ( $\mathrm{IC}_{50}$ value of $260,2 \mu \mathrm{g} / \mathrm{ml}$ ) showing a concentration dependent manner, with $\mathrm{IC}_{50}$ of $90,6 \pm 0.97 \mu \mathrm{g} / \mathrm{ml}$. Beside, the cytotoxic effect of chloroform and $n$-hexane fraction from Annona muricata $\mathrm{L}$ on Hela cell with $\mathrm{IC}_{50}$ value of $127,3 \mu \mathrm{g} / \mathrm{ml}, 169,2 \mu \mathrm{g} / \mathrm{ml}$ respectively. Decreasing cell viability may be because of either cell death or cell cycle arrest. In conclusion, chloroform fraction from Annona muricata Linn leaves indicate has potential to be developed as a co-chemotherapeutic agent on Raji and Hela cell lines. Further molecular target detection to investigate its cellular pathway needs to be conducted.

\section{Acknowledgmen}

We thank to acknowledge Higher Education Competitive Research Project Ministry of Education and Culture Republic of Indonesia for Grand Featured Research. 


\section{Reference}

C. C. Liaw, F.-R. Chang, C.-Y. Lin, C.-J. Chou, H.-F. Chiu, M.-J. Wu and Y.-C. Wu, "New Cytotoxic Mono- tetrahydrofuran Annonaceous Acetogenins from Annona muricata," Journal of Natural Products, Vol. 65, No. 4, 2002, pp. 470-475.

Chen, J.C, Hsu, W.L, Yang, H.I, Lee, M.H, Chen, H.C, Chien, Y.C, and You, S.L, 2014, Epidemiology of Virus Infection and Human Cancer, Cancer Research : 193.

Forman, D., Catherine de Martel, Lacey, C.J., Soerjomataram, I., Lortet-Tieulent, J., Bruni, L., Vignat, J., Ferlay, J., Bray, F., Plummer, M., Franceschi, S. 2012. Global Burden of Human Papillomavirus and Related Diseases. Vaccine 30S: F12- F23.

IARC. 2009.International Agency for Research on Cancer A review of human carcinogens. Part B: biological agent. IARC, Lyon, IARC.

Leaver, D. and Labonte, G. 2010. HPV and Cervical Cancer. Radiation 19, $27-44$.

Lee, Young-Man, Jeong, Gil-Saeng, Lim, Hyun-Dae, An, Ren-Bo, Kim, YounChul, and Kim, EunCheol, 2010. 'Isoliquiritigenin 2'-methyl ether induces growth inhibition and apoptosis in oral cancer cells via heme oxygenase- 1 .

Miller, R.P., Tadagavadi, R.K., Ramesh, G., and Reeves, W.B. 2010. Mechanisms of Cisplatin Nephrotoxicity. Toxins 2: 2490-2518.

Mukherjea, D. and Rybak, L.P. 2011. Pharmacogenomics of cisplatin-induced ototoxicity. Pharmacogenomics 12(7): 1039-1050.

Newman, D.J, dan Cragg, G.M, 2007, Natural Products as Sources of New Drugs Over The Last 25 Years, J. Nat. Prod, 70: 461-477.

Prayong, P., Barusrux, S., and Weerapreeyakul, N., 2008, Cytotoxic activity screening of some indigenous Thai plants", Fitoterapia, 79(7-8), hal. 598- 601.

Rabik, C.A., and Dolan, M.E. 2007. Molecular mechanisms of resistance and toxicity associated with platinating agents. Cancer Treatment Reviews, 33: 9- 23.

Sirichanchuen, B., Pengsuparp, T., and Chanvorachote, P. 2012. Long-term cisplatin exposure impairs autophagy and causes cisplatin resistance in human lung cancer cells. Mol Cell Biochem 364:11-18. 